\title{
Where are All the Female Innovators? Nurses as Innovators in a Public Sector Innovation Project
}

\author{
Johanna Nählinder'
}

\begin{abstract}
The individual innovator is seldom seen in innovation research, but there is still an implicit understanding that men are more innovative than women, and that men-dominated occupations are more innovative than women-dominated ones. The female nurse is one among those who are not seen as innovative and few innovation policies target her. In this paper, two of the many factors that determine the alleged lack of innovativeness of women are tested empirically: that women work in occupations which are not associated with innovation; and that women lack the self-confidence to carry out innovative work. Our results show that there are gender differences in favour of women regarding the creativity and innovativeness of employees within the same care sector occupation. Men and women end their innovative efforts for different reasons and the innovativeness of women is sometimes hampered by low self-confidence and low prioritization of work issues over family or household issues. Overall, innovation policies targeting these groups are needed to mobilize otherwise dormant potential innovators.
\end{abstract}

Keywords: gender; innovator; innovation policy; occupation; care-sector.

\footnotetext{
' Department of management and engineering and Helix Excellence Centre, Linköping University, SE-58I 83. LINKÖPING, Sweden. Phone: +46(0) I 3-28I 536. Email: Johanna.nahlinder@liu.se
} 


\section{Introduction}

Innovation studies usually focus on processes and organizations, and only seldom focus on people or the individual innovator. With some notable exceptions, the innovator as an individual and the gender of the innovator do not play a prominent role in innovation studies. For example, the influential Oxford Handbook of Innovation (2005) mentions "women" four times, but in none of these cases it is women as innovators. It also mentions "gender" twice, when naming variables that influence labour supply and diffusion of consumer durables, but it does not mention "sex" even once (Powell, 2005; Mowery and Sampat, 2005; Tunzelmann and Acha, 2005; Hall 2005; Pianta, 2005). A similar pattern can be seen in the third Oslo Manual (2005), the guide for collecting and interpreting innovation data, where the words "woman" and "sex" are not mentioned at all. The word "gender" is mentioned once, in the context of collecting data on human resource management. Other examples of the relatively limited research on women innovators includes biographies of female innovators (cf. Gammel, 2002, Curry, 2009 and Beyer, 2009), or broader discussions of the gender of the innovator in the fields of fashion (Beaudoin et al., 2003; Muzinich et al., 2003; Uray and Dedeoglu, 1998), education (Warwick et al., 1992; Paechter, 2003) and farming (Reij and Waters-Bayer, 200 I; Kibwana et al., 200I).

Innovation is not gender-neutral; rather, it is genderbiased, since there is a general perception that women are less innovative than men. For example, Nyberg (2009) finds that approximately 5\% of (Swedish) patent-holders are female, which suggests that female inventors ${ }^{2}$ in Sweden are a very small minority. Figures from the Swedish regional semi-public business support firm ALMI Östergötland also confirm that women innovators are in the minority: $31 \%$ of persons requesting support for innovative ideas from this organisation in 2008 were female (ALMI, 2009), a proportion that, although still low, increased significantly in comparison with the $10 \%$ share of two years previously.

If innovation studies are little concerned with gender, the adjacent research field of entrepreneurship is much more

\footnotetext{
${ }^{2}$ We are aware of the role of patents as a measure of inventions, not of innovations, but we consider inventions here as a component of innovation, and therefore use patents as an indirect measure of innovation.
}

prone to see the person behind the venture - the entrepreneur - and does not remain exclusively focused on the venture or entrepreneurial process ${ }^{3}$ (e.g. Shane and Venkataraman, 200I; Erikson, 200I; Singh, 200I; Zahra and Dess, 200I). Research on female entrepreneurship has become more prominent in recent years (cf. Sundin and Holmquist, 1989; Moore, 1990; Greene et al. 2004) and shows significant differences between men and women. For example, social constructivist Helen Ahl (2002) shows that female entrepreneurs are not considered to be as important as (male) entrepreneurs and that academic article on female entrepreneurship reinforce women's secondary position in society.

Several factors appear to be of critical importance in explaining why women are less visible as inventors, innovators or entrepreneurs than men:

\section{a) Self-confidence}

Self-confidence is usually examined in relation to motivation, which is a key issue addressed in entrepreneurship studies (cf. Klofsten and Davidsson, 2003). Self-confidence is influenced by the gender of the entrepreneur and in turn, influences their success. Women entrepreneurs have been shown to share many common traits with male entrepreneurs with respect to what motivates them: economic necessity, the need to achieve, to be independent, to increase job satisfaction, etc. (Brockhaus and Horwitz, 2002). Among various motivational aspects, only self-confidence was found to differ between men and women entrepreneurs (Birley, 1989). Kirkwood (2009) found that the lower selfconfidence of women entrepreneurs has a negative impact upon female entrepreneurship and is one explanatory factor why women start new ventures to a lower degree than men.

\section{b) Personal Characteristics of Male and Female Entrepreneurs}

Female entrepreneurs tend to have supportive parents and husbands, they are older than male entrepreneurs, better educated, and usually have self-employed fathers (Brockhaus and Horwitz, 2002). It appears that women

\footnotetext{
${ }^{3}$ We acknowledge that the concepts of entrepreneur and innovator are not synonymous, although they may sometimes be used in close association.
} 
need the advantages of age, role models, support and education in order to succeed as entrepreneurs. Other gender differences in terms of personal characteristics have also been found, including differences in creativity (Reis, 2002), role expectations (Millward, 2000) and risktaking (Belcourt, 2009).

\section{c) Occupational Choice}

Women and men tend to work in different occupations. This is a well-known labour market phenomenon, referred to as horizontal or occupational segregation (cf. Anker 1997). There is a general perception that women work in occupations that are not usually associated with innovation. For example, addressing the question of why female innovators (or rather inventors) are not as common as male innovators, Nyberg (2009) finds that being an innovator is not regarded as a feminine trait even by the female inventors themselves, since the image of the inventor is not easily compatible with the image of being a woman. The image of the inventor is that he is a nerd. The male nerd image of the inventor is not attractive to everyone, especially not to women. The reluctance to identify themselves with the (nerd) inventor, does not, however, prevent the women from feeling a sense of pride over what they have accomplished.
Nyberg (2009) argues that the social visibility of technology is higher in men-dominated sectors than in womendominated sectors, such as care and textiles:

"Just like technology has become almost invisible within sectors of society that are considered to be feminine, like e.g. care work, which is dominated by women, women have also become almost invisible as actors within sectors of society that are considered masculine, e.g. technology in the conventional sense, which is dominated by men." (Nyberg, 2009:127)

Nyberg (2009) makes a connection between actor (man/woman), sector (dominated by men/dominated by women) and technology, suggesting that the social visibility of technology depends not only on the sector, but also on the gender of the actors, which could be a consequence of an historical inability to detect female innovativeness. This argument is summarized in a four-field matrix of sectors and actors, where technology is visible in only one cell (Figure I). The male coding of technology, and thereby also of innovation, has consequences well beyond semantics; for instance, it will result in the public perception that most innovators are men, and that what women do is not innovative.

\begin{tabular}{|l|l|l|}
\hline & Sector: dominated by women & Sector: dominated by men \\
\hline Actor: women & Technology is invisible & Technology is invisible \\
\hline Actor: men & Technology is invisible & Technology is visible \\
\hline
\end{tabular}

Figure I. Sector and actor in relation to technology. Source: Based on Nyberg (2009), p I27.

Taking Nyberg's matrix shown in Figure I one step further, we argue that the important unit is not the sector, but rather the occupation within a sector, since the occupation is a more fine-tuned indicator within the respective sector. We therefore relate innovation not only to horizontally-segregated occupations, but also to the gender of the person who works within the occupation (Figure 2). The same sector (for example medical care) employs people in several occupations, which are more or less horizontally segregated: for example, the care sector in Sweden (SSYK 2008) employs inter alia medical engineers (more than $90 \%$ of the employees are men), physicians (gender-balanced), nurses and assistant nurses (more than $90 \%$ of the employees are female). These occupations, although they are in the same sector, have very different gender structures. Secondly, the visibility of innovation is more relevant than the visibility of technology, although the two are related. Not all innovations concern technology - innovations are also made and recognised in non-technological products and processes. Some male-segregated occupations (such as engineers) are highly associated with innovation, while some female-segregated occupations (such as nurses) are not associated with innovation: their problem-solving is not seen as innovation. 


\begin{tabular}{|l|l|l|}
\hline & Women-segregated occupation & Men-segregated occupation \\
\hline Actor: women & Invisible problem-solving & Invisible problem-solving \\
\hline Actor: men & Invisible problem-solving & $\begin{array}{l}\text { Visible problem solving (as } \\
\text { innovation) }\end{array}$ \\
\hline
\end{tabular}

Figure 2. Occupation and actor in relation to innovation and problem-solving

\section{d) The Theory of the Gender System}

Figure I, as well as the quote by Nyberg above, suggests that the problem-solving skills of a woman in a mensegregated sector are less likely to be regarded as innovation. Why, then, would the problem-solving skills of a man in a men-segregated occupation, be more visible as innovation? The theory of the gender system, which is a tool for describing the power relation between men and women (Hirdmann, 1990) sheds some light. Here, the gender system is seen as based on two phenomena: segregation (women and men are segregated by law or by other means, including informal ones) and hierarchisation (the male is the rule and standard, and thereby is more highly valued). One common example is the difference between soccer and women's soccer, where the first is seen as the standard and receives more attention. Another example is the separation of female entrepreneurs from entrepreneurs, which, as discussed above, led to a hierarchisation where male entrepreneurship is more esteemed than female entrepreneurship. A third example from the area of innovation is the concept of wominnovation, recently introduced by The Economist to describe innovations which specifically empower women, such as microcredit, mobile telephones and birth control pills (The Economist, March $9^{\text {th }}$ 2010). No equivalent term for men such as "minnovations", has been suggested. Although a genderawareness is inherent in the concept of wominnovations, the term still reinforces the pattern of hierarchisation: the male is the rule and standard and wominnovations are deviations from that pattern.

In this paper, the focus is on a particular womensegregated set of occupations: nurses and assistant nurses, whose problem-solving is seldom described in terms of innovation. The care workers typically solve problems on a routine basis, but these solutions are seldom diffused or verbalised. Problem-solving in this sector is taken for granted, but is in many regards the opposite of our image of innovation, in spite of the underlying innovation potential of the sector, because it is usually performed by women in labour-intensive work categories. And it is not technology.

The purpose of this article is to advance our understanding of why women are seen as innovating less than men, by analysing an innovation support project in the care sector. The paper is structured as follows: we start with a description of a project supporting innovation in the public care sector (PIMM), which forms the basis of our study, and continue with a presentation of the project methodology. Next, we describe and discuss the results of a statistical analysis of data collected within the project and conclude with the policy and theoretical implications of the results.

\section{Description of the Empirical Case}

The PIMM project (product development in the care sector) was launched in 2006 in the Swedish region Östergötland with the aim of supporting innovation among public health care workers over the period 2006-2010. The launch of this project reflects the attention paid to the public sector, in general, where innovation only recently has become an issue, and to the care sector, in particular, which has seldom been the focus of innovation support. PIMM is targeted to both men and women who work in the care sector and have different occupational backgrounds, encouraging them to see themselves as potential innovators, to present more ideas and also to become more innovative. In particular, the project has the potential to attract an unusual target group: nurses and assistant nurses, two highly horizontallysegregated occupations. Official statistics show that in Sweden $91 \%$ of all nurses and $93 \%$ of all assistant nurses are women (SSYK 2008).

PIMM is a joint project between several organisations, most of them public. The owner of the project is the

ISSN: 07I 8-2724. (http://www.jotmi.org)

Journal of Technology Management \& Innovation @ Universidad Alberto Hurtado, Facultad de Economía y Negocios 
intermediary New Tools for Health, the project leader comes from public-owned SME-support firm ALMI Företagspartner. The other participants are the regional development council Östsam, the county council of Östergötland, and the municipalities of Norrköping and Motala. The PIMM commissioners thus represent not only innovation policy agencies, but also care agencies.
PIMM aims at supporting and assisting public care employees to present and process their ideas into licensed products or services. A simplified outline of the PIMM idea qualification process is presented in Figure 3. This paper focuses on the first two steps of the idea qualification process: the initial ideas and the first selection of ideas.

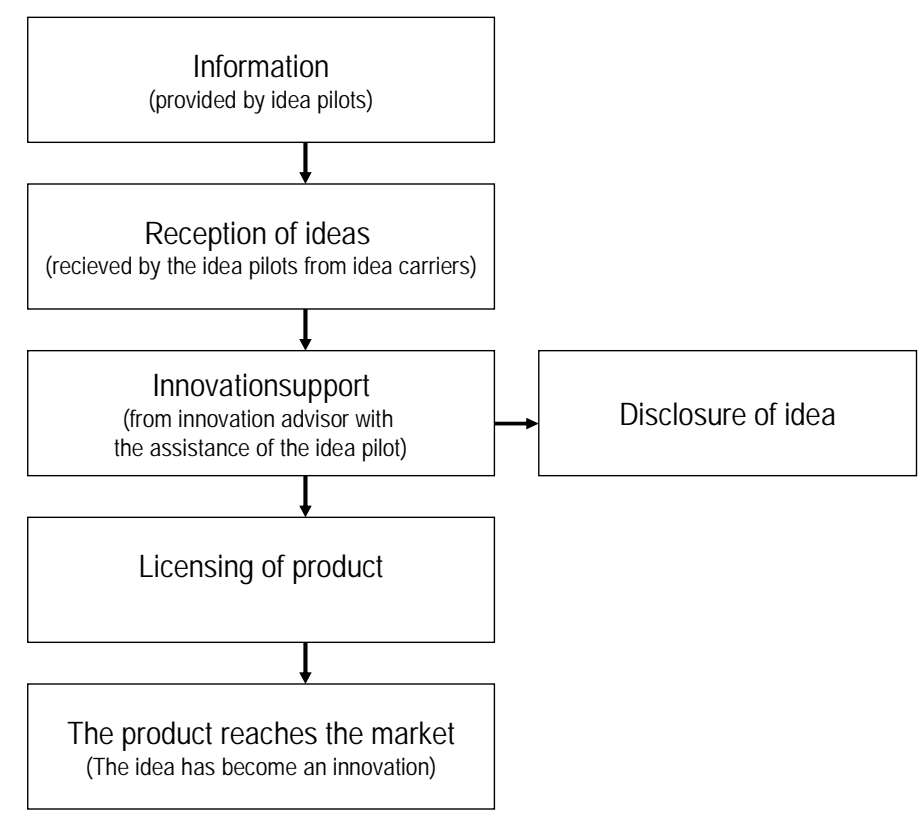

Figure 3. Idea qualification process of PIMM. Source: adapted from ALMI (2006).

PIMM has assigned and trained three peers (referred to as "idea pilots") to inform the employees of the possibility of presenting and processing their ideas. The employee who approaches the project with an idea (referred to as "idea carrier") typically contacts the idea pilot, and they discuss the idea in a subsequent meeting. An innovation advisor, assisted by the idea carrier and idea pilot, develops and protects the idea and finally licenses it to a firm. A majority of ideas succumb in the idea qualification process for various reasons and do not make it to the stage of commercialisation where the innovative potential of the idea could be fully exploited

The idea pilots are pivotal to the project. They play a bridging role between the everyday work environment of the care workers and the innovation advisor. In particular, they play an important role in encouraging women to believe in their own ideas. The idea pilots hold presentations to peers, which are meant to be 'eye- openers' ("you too can be an innovator!"), but mostly aim at recruiting potential idea carriers. They facilitate the first meetings with the innovation advisor and are involved in parts of the idea qualification process together with the idea carrier and the innovation advisor. Initially, the project envisaged a clear break between the tasks of the idea pilot and the innovation advisor. However, as the project developed, these two functions became increasingly overlapping, showing both a need for support and ability of the nurses to carry out innovation advisor tasks.

All three idea pilots have an occupational background in nursing or care, not as medical engineers, or physicians. This background is a criterion for their selection and reflects the project focus on nurses and assistant nurses. The idea pilots receive training in order to strengthen their idea qualification skills. All three idea pilots are female, and at least two of them make reference to 
women's ability to innovate when presenting the project to their peers. Another indication of the project's intention to attract female idea carriers is that the project logo is pink.

The idea pilots contact peers both in person (workplace meetings) and through media, such as posters and intranet. All three idea pilots work in large organisations, for example in the county council, which has II 200 employees (County Council 2010a). At least $90 \%$ of these employees work in the care sector and about half are nurses or assistant nurses (County Council 20l0b, my calculations). Available data shows that $83 \%$ of the county council employees, $93 \%$ of the Norrköping municipality and 89 percent of the Motala municipality employees are female.

The project is still running (it will run until July 2010) and has already led to innovations, including: the pyjamas for incontinent dementia patients, which prevents them from removing the diaper, the catheter underpants, which facilitates movements while wearing a catheter, the lotion-guide which facilitates the choice of medical lotions, the skirt-peg, which facilitates assisted toilet visits for patients with skirts. The innovations emerged so far have three common aspects: (i) they are not technologically advanced, (ii) they are everyday innovations, and (iii) they are product innovations, despite the fact that the idea carriers are service providers.

\section{Method and Research Design}

The PIMM project database originated from a collection of incoming ideas reported to the project by the idea carriers and organized by the project leader, the innovation advisor and the idea pilots. It is important to note here that the database includes incoming ideas, and not idea carriers, since the same idea carrier may contribute with more than one idea. In November 2009, the database included 306 incoming ideas, each of them being associated with the occupation and the gender of the idea carrier, and with the mention of whether or not the idea has been discontinued. Most information on the database is confidential, but some variables have been approved for research.

The research questions addressed in this paper are the following:

RI: Are there gender differences regarding the innovativeness of employees within the same care sector occupation?

R2: Are there gender differences in the success of incoming ideas to pass the qualification process?

R3: Are there gender differences in the reasons for which ideas are discontinued from the qualification process?

R4: Is women's innovativeness hampered by low selfconfidence?

These research questions will be answered using:

a) Quantitative analysis (for research questions I-3) based on the variables defined in Table I. The four variables are categorical. Among them, Gender, Occupation and Incoming ideas are dichotomous: Gender can only take two values (Male or Female), Occupationwais assigned only two values: 'Nurses et al..' (nurses, assistant nurses and non-trained assistants with a caring profile) or 'Others' (all other occupations have been re-coded into one of these two occupational categories), and Incoming ideas can also only take two values (Qualified or Discontinued). The fourth variable, Reason for idea discontinuation, takes one of the five values described in Table I.

Non-parametric statistics, more precisely two different types of chi square tests (contingency table and goodness of fit) have been used for the Gender and Occupation categorical variables to determine if the distribution of an observed frequency differs from the expected frequency (Siegel and Castellan, 1988). 


\begin{tabular}{|c|c|c|c|}
\hline $\begin{array}{l}\text { Variable } \\
\text { name }\end{array}$ & $\begin{array}{l}\text { Variable } \\
\text { definition }\end{array}$ & $\begin{array}{l}\text { Variable } \\
\text { type }\end{array}$ & Possible variable values and number of observations \\
\hline Gender & $\begin{array}{l}\text { Sex of the idea } \\
\text { carrier }\end{array}$ & $\begin{array}{l}\text { Categorical } \\
\text { (dichotomous) }\end{array}$ & $\begin{array}{l}\text { Male (9I) } \\
\text { Female (2I5) }\end{array}$ \\
\hline Occupation & $\begin{array}{l}\text { Occupation of } \\
\text { idea carrier }\end{array}$ & $\begin{array}{l}\text { Categorical } \\
\text { (dichotomous) }\end{array}$ & $\begin{array}{l}\text { 'Nurses et al.': Nurses, assistant nurses, non-trained assistants } \\
\text { with a caring profile (166) } \\
\text { “Other": all occupations other than 'nurses et al.' (I40) }\end{array}$ \\
\hline Incoming ideas & & $\begin{array}{l}\text { Categorical } \\
\text { (dichotomous) }\end{array}$ & $\begin{array}{l}\text { "Qualified idea": the idea has not been discontinued and has } \\
\text { gone through the qualification process (143) } \\
\text { "Discontinued idea": the idea has been discontinued (163) }\end{array}$ \\
\hline $\begin{array}{l}\text { Reason for } \\
\text { discontinuation }\end{array}$ & $\begin{array}{l}\text { Primary reason } \\
\text { for } \\
\text { discontinuation } \\
\text { of an idea } \\
\text { (established by } \\
\text { the innovation } \\
\text { advisor) }\end{array}$ & Categorical & $\begin{array}{l}\text { "Idea already exists": the problem to which the idea is a } \\
\text { solution has at least one previously marketed solution (90) } \\
\text { "Idea not necessary": potential users show no interest in } \\
\text { purchasing a possible solution to the problem (17) } \\
\text { “Idea not functional": the solution suggested is not possible } \\
\text { to manufacture (I8) } \\
\text { "Discontinuation due to idea carrier": the idea carrier (and } \\
\text { not the idea itself) is considered by the innovation advisor as the } \\
\text { primary reason of discontinuation. This includes idea carrier } \\
\text { who is deceased or lost interest in their idea (19) } \\
\text { "Not elsewhere classified" (nec): all other reasons for } \\
\text { discontinuation not included above (19) }\end{array}$ \\
\hline
\end{tabular}

Table I. Summary of variables used in the statistical analysis

b) Qualitative analysis (for research question 4): the author has followed the PIMM project closely since September 2006 and collected qualitative data from over 40 different occasions, including attendance at meetings and interviews with different stakeholders. An additional group interview with the project leader, idea pilots and innovation advisor has been held to clarify the issue of selfconfidence. The group interview was held in conjunction with a project group meeting at the workplace of one of the idea pilots. It was recorded and partly transcribed. The interview was semi-structured around seven broad questions, of which three focused on the issue of self- confidence ${ }^{4}$. In total, the discussion took 257 minutes.

Most of the care workers involved in PIMM are women. This finding is further analysed in the context of the gender

\footnotetext{
${ }^{4}$ The interview was structured around the following questions:

"Looking back at PIMM, what has been the most important experience?", "If you were to re-do the project with the experience you have today, what would you do?", "Mention one thing that would make more innovations reach the market", "Why do idea carriers discontinue their ideas?", "In your opinion is the discontinuation of ideas due to self-confidence", "Do different groups of idea carriers differ in self confidence?", "Do different groups of idea carriers differ in initiative capacity?"
} 
structure of all occupations in Sweden, which was derived from Statistics Sweden (2008) and is presented in the first column of Table 2. We see here that all occupations in Sweden are divided into:

- Extremely man-segregated occupations (more than $90 \%$ working within the occupation is male);

- Men-segregated occupations (between $90 \%$ and $60 \%$ of all working in the occupation is male);

- Gender-balanced occupations (between 60\% and $40 \%$ of each gender is represented);

- Woman-segregated occupations (between $90 \%$ and $60 \%$ of all working in the occupation is female) and

- Extremely woman-segregated occupations (more than $90 \%$ working within the occupation is female).

The first column of Table 2 shows that only 7I out of 356 occupations in Sweden are gender balanced. However, we must keep in mind that occupations vary in size: some occupations are very small with only a few practitioners.
The next column of Table 2 present the structure of the stated occupations in the PIMM database that have been analysed in the light of the occupations described in the Statistics Sweden database (SSYK 2008). We see thus that 24 occupations have been identified in PIMM and they have been further divided into two occupational categories: 'Nurses et al.' and 'Other'.

Comparing the gender segregation of PIMM occupations (columns 2-4 of Table 2) to that of all occupations in Sweden (first column of Table 2), we see that out of the I28 Men-segregated occupations in Sweden only one is represented in PIMM, more precisely in the 'Other' category. Also, out of the 18 Extremely women-segregated occupations in Sweden, 10 are represented in PIMM, of which 8 in the category 'Nurses et al.' We can therefore consider that 'Nurses et al.' is an example of Womensegregated occupations (which, according to Nyberg, would not be seen as innovative). The heterogeneous category of 'Other' is less women-segregated than 'Nurses et al.'

\begin{tabular}{|c|c|c|c|c|}
\hline & $\begin{array}{l}\text { All occupations in } \\
\text { the Swedish } \\
\text { economy }\end{array}$ & $\begin{array}{l}\text { Occupations } \\
\text { identified among } \\
\text { PIMM idea carriers }\end{array}$ & $\begin{array}{l}\text { Occupations } \\
\text { identified among } \\
\text { 'Nurses et al.' }\end{array}$ & $\begin{array}{l}\text { Occupations } \\
\text { identified among } \\
\text { 'Other' }\end{array}$ \\
\hline $\begin{array}{l}\text { Extremely men-segregated } \\
\text { occupations (>90\% men) }\end{array}$ & 66 & 0 & 0 & 0 \\
\hline $\begin{array}{l}\text { Men-segregated occupations } \\
\text { (60-90\% men) }\end{array}$ & 128 & I & 0 & I \\
\hline Gender-balanced occupations & 71 & I & 0 & I \\
\hline $\begin{array}{l}\text { Women- segregated } \\
\text { occupations }(60-90 \% \text { women })\end{array}$ & 73 & 12 & 6 & 6 \\
\hline $\begin{array}{l}\text { Extremely women- segregated } \\
\text { occupations (>90\% women) }\end{array}$ & 18 & 10 & 8 & 2 \\
\hline Sum & 356 & 24 & 14 & 10 \\
\hline
\end{tabular}

Table 2. Number of occupations by degree of horizontal segregation in the Swedish economy as a whole, in PIMM and in the two occupational groups of PIMM.

Source: calculations based on SSYK (2008), Statistics Sweden and the PIMM database. 


\section{Results}

The presentation of results described below is organised around the research questions described above.

RI: Are there gender differences regarding the innovativeness of employees within the same care sector occupation?

The innovativeness of the employees is measured here by:

- The number of incoming ideas: this is an indirect measure of employees' innovativeness, as the ideas reported in the PIMM project are neither inventions, nor innovations. They are creative solutions to existing every-day problems and therefore can be considered as a measure of the employees' creativity, rather than innovativeness. However, as creativity is an essential initial stage in the process of innovation, we consider them an indirect measure of employees' innovativeness.

Table 3 shows that the majority of incoming ideas in PIMM by gender ( 215 out of $306,70.3 \%$ ) come from a female idea carrier. There is also a majority of incoming ideas in PIMM by occupational category, with more than half (54.2 \%) of coming from 'Nurses et al.', i.e. nurses, assistant nurses and assistants with a care profile. These figures suggest that there are gender differences in favour of women in the creativity and indirectly, also in the innovativeness of employees within the same care sector occupation.

\begin{tabular}{|l|l|l|l|l|}
\hline & Women & Men & Total & Share women (\%) \\
\hline 'Other' & 79 & 61 & 140 & $56.4 \%$ \\
\hline 'Nurses et al..' & 136 & 30 & 166 & $81.9 \%$ \\
\hline Total & 215 & 91 & 306 & $\mathbf{7 0 . 3 \%}$ \\
\hline $\begin{array}{l}\text { Share 'Nurses et al.' } \\
(\%)\end{array}$ & $63.3 \%$ & $32.9 \%$ & $\mathbf{5 4 . 2} \%$ & \\
\hline
\end{tabular}

Table 3. Number of incoming ideas by gender and occupational category. Source: calculations based on PIMM database.

In order to test whether the number of incoming ideas in the two occupational categories 'Nurses et al.' and 'Other' are significantly different from each other, a chi square contingency table test was conducted. The result is significant (chi2 value: 23.63; level of significance $\mathrm{p}<0.00 \mathrm{I}$ ), meaning that the two categories are different from each other. This confirms that the group of 'Nurses et al.' is more horizontally segregated than the 'Other' group in terms of incoming ideas.

- $\quad$ The number of qualified ideas - is a direct measure of employees' innovativeness, which shows not only the number of ideas that have successfully gone through the qualification process but also provide a measure of the employees' commitment to realise the innovative potential of their ideas, as well as a measure of the contributions made by the idea pilots and innovation advisor, reflecting the collective nature of the innovation process encouraged within the project.

Table 4 shows that $67.8 \%$ of qualified ideas by gender belong to women and $53.8 \%$ of qualified ideas by occupational category come from "Nurses et al." 


\begin{tabular}{|l|l|l|l|l|}
\hline & Women & Men & Total & Share women (\%) \\
\hline 'Other' & 33 & 33 & 66 & $50.0 \%$ \\
\hline 'Nurses et al.' & 64 & 13 & 77 & $83.1 \%$ \\
\hline Total & 97 & 46 & 143 & $\mathbf{6 7 . 8 \%}$ \\
\hline $\begin{array}{l}\text { Share 'Nurses et al.' } \\
(\%)\end{array}$ & $65.9 \%$ & $28.2 \%$ & $\mathbf{5 3 . 8 \%}$ & \\
\hline
\end{tabular}

Table 4. Number of qualified ideas by gender and occupational category.

Source: calculations based on PIMM database.

Correlating these figures with those seen in Table 3, we can say that the gender differences in favour of women found in creativity are matched by gender differences in favour of women in the number of qualified ideas.

R2: Are there gender differences in the success of incoming ideas to pass the qualification process and become innovations?

The success of incoming ideas to pass the qualification process is primarily indicated by the number of qualified ideas (Table 4). As shown above, $67.8 \%$ of qualified ideas by gender belong to women and $53.8 \%$ of qualified ideas by occupational category come from "Nurses et al.", which suggests that women are more successful than men in going through the qualification process.

Another indirect measure of the success of incoming ideas to pass the qualification process is the number of discontinued ideas. Table 5 shows that $72.4 \%$ of all discontinued ideas by gender come from women, and $54.6 \%$ of all discontinued ideas by occupational category come from 'Nurses et al..' These figures suggest that women outnumber men in the number of discontinued ideas.

\begin{tabular}{|l|l|l|l|l|}
\hline & Women & Men & Total & Share women (\%) \\
\hline 'Other' & 46 & 28 & 74 & $62.2 \%$ \\
\hline 'Nurses et al.' & 72 & 17 & 89 & $89.9 \%$ \\
\hline Total & 118 & 45 & 163 & $\mathbf{7 2 . 4 \%}$ \\
\hline $\begin{array}{l}\text { Share 'nurses et al.' } \\
(\%)\end{array}$ & $61.0 \%$ & $37.7 \%$ & $\mathbf{5 4 . 6 \%}$ & \\
\hline
\end{tabular}

Table 5. Number of discontinued ideas by gender and occupational category. Source: calculations based on PIMM database.

R3: Are there gender differences in the reasons for which ideas are discontinued from the qualification process?

Analysing Table 6 below, which presents the reasons for idea discontinuation, it may be noted that:

- 'Idea already exists': this is the most common reason why an idea is discontinued in PIMM: 90 out of the 163 discontinued ideas are associated to this reason. At first glance, it may appear that there is a large difference by gender: 71 out of the 118 discontinued ideas belong to women (i.e. 60\%), compared to 19 out of the 45 ideas discontinued by men (i.e. 42\%), and almost no difference by occupational category: 48 out of the 89 
discontinued ideas (i.e. 53.9\%) belong to 'Nurses et al..', compared to 42 out of the 74 discontinued ideas (i.e. 56.7\%) that belong to 'Other'. However, the difference is not statistically significant (chi2 value: 2.25; level of significance $0.5<p<0.10$ ).

- 'Idea not necessary': Female nurses are less successful in identifying a need, but the difference is not statistically significant (chi2 value: 3.57 ; level of significance $0.10<p<0.05$ ).

- 'Idea not functional': 18 ideas have been discontinued due to technical non-functionality.
Here, gender and occupation is statistically different from what would be expected (chi2 value: 8.69; level of significance $0.01<p<0.00 \mathrm{I}$ ). The ideas of women nurses function to a higher degree than expected, while the ideas of men non-nurses fail to a greater degree than expected.

- 'Discontinuation due to idea carrier': this is a reason largely attributed to women (18 cases) and only rarely to men ( 1 case). The difference is statistically significant (chi2 value: 5.36 ; level of significance $0.05<p<0.0$ I).

\begin{tabular}{|l|l|l|l|l|l|l|l|l|l|}
\hline & \multicolumn{6}{|c|}{ By gender and occupational category } & \multicolumn{2}{c|}{$\begin{array}{l}\text { By occupational } \\
\text { category only }\end{array}$} & \\
\hline $\begin{array}{l}\text { Reason for idea } \\
\text { discontinuation }\end{array}$ & Women & $\begin{array}{l}\ldots \\
\text { Of which } \\
\text { 'Nurses } \\
\text { et al.' }\end{array}$ & $\begin{array}{l}\ldots \\
\text { Of } \\
\text { which } \\
\text { 'Other' }\end{array}$ & Men & $\begin{array}{l}\ldots \\
\text { Of which } \\
\text { 'Nurses et } \\
\text { al.' }\end{array}$ & $\begin{array}{l}\ldots \\
\text { Of } \\
\text { which } \\
\text { 'Other' } \\
\text { et al.' }\end{array}$ & 'Other' & Total \\
\hline Idea already exists & 71 & 42 & 29 & 19 & 6 & 13 & 48 & 42 & 90 \\
\hline Idea not necessary & 13 & 11 & 2 & 4 & 2 & 2 & 13 & 4 & 17 \\
\hline Idea not functional & 8 & 3 & 5 & 10 & 3 & 7 & 6 & 12 & 18 \\
\hline $\begin{array}{l}\text { Discontinuation due } \\
\text { to idea carrier }\end{array}$ & 18 & 10 & 8 & 1 & 1 & 0 & 11 & 8 & 19 \\
\hline $\begin{array}{l}\text { Not elsewhere } \\
\text { classified }\end{array}$ & 8 & 6 & 2 & 11 & 5 & 6 & 11 & 8 & 19 \\
\hline Total & 118 & 72 & 46 & 45 & 17 & 28 & 89 & 74 & 163 \\
\hline
\end{tabular}

Table 6. Reason for discontinuation of ideas by gender and occupational category.

Source: calculations based on PIMM database.

R4: Is women's innovativeness hampered by low selfconfidence?

When asked if ideas are discontinued due to low self confidence of the idea carrier, the idea pilots interviewed have been reluctant to describe it as an issue of self confidence per se. Rather, they described it as an issue of prioritization, which, they said, is shaped differently by gender difference. As one of the idea pilots put it:

I do not think that they do not believe in their idea. I think they prioritize, and this is not as important as, for example, taking care of the grandchild when your daughter goes back to work. ...We do different things as women and men. It is not the man who stays home for six months taking care of the grandchild while the daughter goes back to work. But you do not prioritize working with your own idea. (Idea pilot I)

Self-confidence was also related to the culture of the nursing organisations, which is strongly influenced by the jantelag ${ }^{5}$, a cultural aspect that prevents idea carriers from

${ }^{5}$ The jantelag is a common cultural reference, based on a book of Aksel Sandemose where the commandment of "Thou shalt not 
showing self confidence. The idea pilots were careful to point out that "It is because they have a very good idea" that an idea was chosen, not because of the effort of the idea carrier. This attitude minimizes the impact of selfconfidence on the idea qualification process since it is the quality of the idea that matters.

Idea pilot 3: But it is the culture... in this organisation... you shall not draw attention to yourself, everyone must be even and be alike.

An implicit opinion in the discussion was that caring occupations have a low status, which also has an impact on the expressed self-confidence of idea carriers:

Idea pilot I: It does not matter that it is you who is there. It could be anyone with your competences. You are just one little head [...] So you are very interchangeable.

The interviewees found that the idea carriers in this project were not exactly "salesmen-type" (i.e. usually very good at daring to present their idea). In contrast, they appreciated that:

"[In healthcare] we get soft people with soft attitudes and maybe we should be glad that we have not got a bunch of salesmen in healthcare”.

"I have one idea carrier who would have [prove the value of the idea to the innovation advisor] - maybe, but others would not have felt up to the task" (Idea pilot I)

Taking into account the inhibiting effects of the jantelag and the implicit belief of the low status of the nursing occupations, the nurses or assistant nurses didn't think that it was part of their normal tasks to push ideas. Therefore, the coaching provided by the idea pilots became necessary and justified. To some extent, this coaching can be seen as the idea pilot taking over part of the responsibilities of the idea carrier as entrepreneur, and the idea carrier's level of self-confidence becomes of little importance to the innovation process. This attitude of the idea carriers with regard to innovative ideas also differed by gender:

fancy thyself better than we" (Sandemose, 1936: 77) was invented. The commandment indicates that it is not appropriate to bring positive attention to oneself.
Idea pilot 2: Above all it is women [who show insecurity regarding their idea]. I have met a lot of men in this project. No man has said that. Some women have.

Some female idea carriers needed a lot of support. Some of them needed to be coaxed into the first meeting with the innovation advisor and they typically expressed concerns about the value of their idea. One idea pilot reflected that:

"It would be so easy to make an idea carrier discontinue their own idea!"

The support staff found that some women appeared to have an urge to be assured that the ideas were good enough. This could thus be interpreted as some women having lower confidence in themselves or in their ideas. On the other hand, the idea pilots pointed to the inhibiting working environment as one reason why these women needed more support and verbal reinforcement in communication.

Self-confidence also appeared to be a matter of occupation: people in some occupations were used to being listened to and having their words lead to action. Only when innovation in healthcare could be successfully analogised to manufacturing, could it be taken seriously and considered as innovation. During this discussion, one of the idea pilots suddenly said:

Idea pilot I: I have not really given it any thought, but now that you bring it up, to motivate an extension of PIMM or such activities in [my municipality], we have used examples from manufacturing: if you do it there, then it must be OK. It is not enough to say that it has been successful in healthcare, you have to compare to something else.

The caring professions have not been expected to be a source of innovation; therefore their practitioners appeared to have a low self-confidence in their ability to innovate even when encouraged to do so - a feature that appeared to be more prominent in women,

\section{Discussion}

Summing up the findings presented above, the answers to the four research questions are:

ISSN: 07I 8-2724. (http://www.jotmi.org)

Journal of Technology Management \& Innovation @ Universidad Alberto Hurtado, Facultad de Economía y Negocios 
RI: There are gender differences in favour of women in the innovativeness of employees within the same care sector occupation. The PIMM project has been a success in attracting women. $70.3 \%$ of all incoming ideas come from women as seen in Table 3, which is an encouraging result. Both the indirect measure of innovativeness (in Table 3) and the direct measurement of innovativeness (in Table 4) show that the project has had a positive impact on the share of innovating women. Men account for approximately $20 \%$ of the ideas among nurses as well as among other occupations. This is a very high share (considering that most occupations in PIMM are female segregated, as seen in Table 2 . It is clear that the project has functioned as an 'eye-opener' to a large previously dormant group of innovators and also showed that the focus on the innovator is a prerequisite for investigating who is innovative. The gender-bias of innovation studies has generated a skewed image of innovation. This is an area which deserves more attention.

R2: There are gender differences in favour of women in going through the idea qualification process, as indicated by the number of qualified ideas (Table 4 showed that $67.8 \%$ of qualified ideas by gender belong to women and $53.8 \%$ of qualified ideas by occupational category come from "Nurses et al."). The number of discontinued ideas, used an indirect measure of the success of incoming ideas to pass the qualification process, showed that $72.4 \%$ of all discontinued ideas by gender come from women, and $54.6 \%$ of all discontinued ideas by occupational category come from 'Nurses et al.' (Table 5). It is important to point out that an idea that was "alive" at the point in which the database was analysed will not automatically result in an innovation - the discontinuation rate is likely to increase before the end of the project. Table 5 only contains the "early shake-out" and it cannot be assumed that other (later shake-outs) discontinued ideas will follow the same distribution over gender and occupation.

R3: There are important gender differences in the reasons for which ideas are discontinued from the qualification process. Men and women discontinue ideas for different reasons. The ideas of women nurses are more functional than expected. Meanwhile, the ideas of men non-nurses are less functional than expected. According to the innovation advisor, men typically report more complex ideas. More complex innovations are more sensitive to functionalityfailure. Most alarming is that women (and not men), discontinue their ideas not due to issues associated with the idea itself or the potential market for the idea, but for personal reasons. A plausible reason why women discontinue their ideas may be that they are pressed for time, due to home care tasks. Pursuing an idea for an innovation may be low-prioritized. It is also possible that something within the project itself has made women less motivated to continue in the idea qualification process.

It is impossible to determine if these ideas would ultimately have become innovations, but the ideas have been discontinued due to the idea carriers, and not due to their viability. There are no indications that these ideas would in any way be inferior to the non-discontinued ideas. Some of these ideas are most probably shipwrecked due to low self-confidence or prioritization. Even if women have the self-confidence to report ideas, they do not necessarily have the self-confidence needed to qualify their idea into an innovation.

R4: The innovativeness of women appears to be hampered by low self-confidence.

Women appeared to be hampered in their innovative efforts in multiple cultural ways, including how they communicate their ideas. Inherent in this cultural communication is the jantelag, which makes them express their ideas as if they do not believe in them. In their communication they did not appear to be self-confident, even if they were. Separating between actual selfconfidence and the apparent self-confidence is very complex.

The idea pilots found that the female idea carriers appeared to be vulnerable to even implicit criticism: they did not believe they would come back if they were challenged to prove that the idea was functional. The idea pilots described how easy it would be to make a female idea carrier to stop believing in her idea and discontinue it. Therefore, I argue, the idea carriers are hampered not only by their lack of self-confidence, but also by the cultural expectations of how a woman and someone with a nursing occupation is supposed to act as well as by a stronger pressure to prioritize home care. The support of the idea pilots has been important to counteract the (lack of) self-confidence of female innovators.

The self-confidence among the female idea carriers is also a question of nurture, as well as nature (see MacKinnon 
1962 for further details on psychology studies on the origin of self-confidence). The working environment of the PIMM idea carriers causes them to adopt a cautious attitude in expressing and promoting themselves. The apparent (lack of) self-confidence of the women idea carriers is thus partly a social construct. The support given by the idea pilots and innovation advisor then offers the opportunity for idea carriers to collaborate to develop their ideas and thus provides the idea carrier with an alternative collective innovation process.

The theory of gender system provides a wider frame of reference which can be used to question the role of confidence. Birley (1989) points to self-confidence as an important difference between male and female entrepreneurs, implying that self-confidence is highly valued in entrepreneurship. Interpreting the lack of selfconfidence as a weakness, which points out strong selfconfidence, or even over-confidence, as the norm and maybe even a prerequisite for successful innovation, is a sign of hierarchisation. Just as it may be questioned why soccer is higher valued than women's soccer, it may be questioned why self-confidence and the ability to speak up for your idea (referred to as 'salesmanship' by the project group) is more highly valued and a pre-requisite for innovation and entrepreneurship.

Within the gender system theory as a frame of reference, the issue of self-confidence is placed on a societal level rather than on an individual level, and opens up the problem for formulation: does low self-confidence inevitably hinder innovation, or is it rather the support system that is not adapted to sufficiently support the idea carriers with low self-confidence or replace them as innovators? What the PIMM project showed was that in the case of the care sector, self-confidence is unnecessarily valued highly, as it is not a necessary condition for innovation due to the collective nature of the process. In a collective innovation and entrepreneurship model, the roles of inventor and innovator may be split and assigned to different persons. Thus, the effect of the idea carrier's lack of self confidence would be minimised.

The formulation of the problem influences what is considered to be the solution. Thus re-framing the problem opens up the way for alternative policy measures, such as the active supporting role of idea pilots in PIMM. This does not necessarily affect the quality of the ideas (i.e. likelihood of innovation), but broadens the range of possible innovators. This too is an area which deserves more attention in order to strengthen support systems and/ or divide invention and innovation tasks.

Returning to the matrix in Figure 2, it is clear that the focus is on what is considered as innovation. In other words, the matrix can be interpreted as above - as number of innovations - but it may also be interpreted as nature of innovation. Innovation is mostly defined as commercialized inventions (Fagerberg, 2005), but different researchers make more or less narrow operationalisations of the concept. Following the Nyberg matrix (Figure I) and what she labels "visible as technology", it may be questioned if the (womandominated) care sector also should incorporate other types of innovation than those found in a men-dominated sector. The paradox is that although it is clear that women (and men) in women-dominated sectors are innovative; it is still the same type of innovations as in men-dominated sectors. It was foreseen that different types of change (organisational innovations, administrative innovations, service innovations) would be reported. Most ideas reported are "conventional" in the sense that they are products, possible to commercialise and possible to protect with IPRs. No organisational innovation or ideas that challenge the conventional view of an innovation have been reported. That means that the routinized problem-solving is typically not reported and is still invisible as technology - as well as invisible as innovation. There is a potential for innovation in these sectors, but the full potential is not detected in the conventional view of innovation. In essence, although women and men in women-dominated sectors are innovative, the nature of innovation has not changed and the type of change visible as innovation has not broadened. Thus, innovation in the care sector is marginalised and invisibilised due to the gendered framing of them as non-innovations.

\section{Conclusions}

Current innovation studies neglect the individual innovator. Innovator capabilities, such as self-confidence and knowledge, may be important to understand why some ideas do not turn into innovations. Most of the small-scale innovations supported in PIMM would not have 
surfaced otherwise. The results of this paper encourage us to re-think the key rationale of innovation and innovation support and question the current focus of innovation policy.

A policy aimed at supporting these capabilities has to reformulate the problem. The lack of self-confidence may be a factor hampering innovation, and in this case, the idea pilots appear to have been a workable tool for mitigating the problem. The results show clearly that PIMM has succeeded in increasing the number and share of ideas from women. The idea pilots have been especially important in this process. The role of the idea pilot goes well beyond scouting for ideas, and this is in part why the system has been so successful. It is tempting to proclaim support people such as idea pilots as a promising instrument for supporting insecure innovators, whatever the reason for their insecurity. On the other hand, there is a dilemma inherent in the use of idea pilots. The idea pilots and the innovation advisor have complained that the idea carriers are a weak link in the qualification of ideas. In fact, when a follow-up-project was designed the role of the idea carrier was much debated. How much assistance should be given to the idea carrier? How much initiative in pushing the idea qualification process forward should come from the idea carrier?

The central role of the idea carrier has been a cornerstone in PIMM. At the same time, it should not prevent us from recognising that innovations are not products of isolated individuals, but rather the outcome of a collective process. In the ideas supported through PIMM, the idea pilot and the innovation advisor are valuable additions to the innovation process, and the network of actors supporting the idea carrier to become an innovator. However, the idea pilot as an instrument for innovation support is a double-edged sword: the idea pilot is crucial to support the idea carrier. However, if the idea pilot becomes too involved, there is a risk that the idea pilot also becomes the carrier of the entrepreneurial geist and in fact becomes the true idea carrier. Thus separating the idea provider from the entrepreneur is a delicate matter, and it presupposes an entrepreneur willing to care for the idea, as well as a structure capable of matching idea and entrepreneur. The original intention of the project was that the idea pilot should not be a substitute for enhancing the motivation of the idea carrier, but to encourage her or him to push the idea qualification process forward.
However, a clear finding of the project was the efficacy of separating the two roles in order to increase the level of innovation attained.

Gender awareness may tease us into re-thinking innovation policy. Innovation policy has typically been directed to the private sector, manufacturing sectors and emergent hightech sectors in terms of provision of funds for developing R\&D into commercialized products. The PIMM project demonstrates the viability of supporting innovation in other areas, such as public ones, and through other means.

Female innovativeness is a means of increasing the number, type and maybe even the quality of innovation. Recognising female innovativeness is crucial to exploit an important potential for innovation. This potential cannot be fully realized with conventional innovation policy instruments.

\section{References}

AHL, H. (2002). The making of the female entrepreneur. A discourse analysis of research texts on women's entrepreneurship. JIBS dissertation series No 015. Jönköping International Business School, Jönköping.

ALMI (2006). Projektplan för PIMM. Produktförnyelse i medicinsk miljö. ALMI, Linköping.

ALMI (2009). Slutrapport projektets kvinnors innovationer. ALMI, Linköping.

BEAUDOIN, P, Lachance, M.J., Robitaille, J. (2003). Fashion innovativeness, fashion diffusion and brand sensitivity among adolescents. Journal of fashion marketing and management, $7(\mathrm{I}), 23-30$.

BELCOURT, M. (2009). Nothing to Lose: Entrepreneurial Behaviour of Female Entrepreneurs. Canadienne des Sciences de l'Administration, 4(2), 199-2I0.

BEYER, K. (2009) Grace Hopper and the invention of the information age. MIT, Cambridge, Mass.

BIRLEY, S. (1989). Female entrepreneurs. Are they really any different? Journal of small business management, 27(I), 32-37.

BROCKHAUS, R. Horwitz, P. (2002). The psychology of the entrepreneur. In: Kreuger, N. (ed) (2002). Entrepreneurship. Critical perspectives on business and management. Routledge, London. 
COUNTY COUNCIL OF ÖSTERGÖTLAND. Fakta om landstinget. County council of Östergötland, County Council web site: http://www.lio.se/Fakta-om-landstinget/ [Accessed March 3I]

\section{COUNTY COUNCIL OF ÖSTERGÖTLAND,} Landstingets medarbetare. County council of Östergötland, County Council web site: http://www.lio.se /Fakta-om-landstinget/Landstingsfakta/Landstingetsmedarbetare/ [Accessed April 20 ${ }^{\text {th }}$ ]

CURRY, R. (2009). "Book reviews.” Journal of women's history. 3I(3), I88-203.

ERIKSON, T. (200I). The Promise of Entrepreneurship As a Field of Research: A Few Comments and Some Suggested Extensions. Academy of Management Review, 26(I), 12-13.

FAGERBERG, J., Mowery, D., Nelson, R. (2005). Oxford Handbook of innovation. Oxford University Press, Oxford.

GAMMEL, I. (2002) Baroness Elsa. Gender, dada and everyday modernity. MIT Press, Cambridge.

GREENE, P. Hart, M. Gatewood, E. Brush, C. Carter, N. (2004). Women entrepreneurs: moving front and center: an overview of research and theory. USASBE Whote paper. USABE, United States association for small business and entrepreneurship web site: http://www.usasbe.org/ knowledge/whitepapers/greene2003.pdf [Accessed April 20]

GREENE, P. Brush, C. Hart, M. Saparito, P. (200I). Patterns of venture capital funding: is gender a factor? Venture Capital, 3(I), 63-83.

HALL, B. (2005). Innovation and diffusion. In: Fagerberg, J., Mowery, D., Nelson, R. (Eds.) Oxford Handbook of innovation. Oxford University Press, Oxford.

HIRDMAN, Y. (1990). Genussystemet. In: Demokrati och makt $i$ Sverige. Maktutredningens huvudrapport. Allmänna förlaget, Stockholm.

KIBWANA, O., Haile, M., Veldhuizen, L. (200I). Clapping with two hands: Bringing together local and outside knowledge for innovation in land husbandry in Tanzania and Ethiopia - a comparative case study. The Journal of Agricultural Education and Extension, 7(3), I33-142.
KIRKWOOD, J. (2009). Is a lack of self-confidence hindering women entrepreneurs? International Journal of Gender and Entrepreneurship, I(2), I I8-133.

KLOFSTEN, M., Davidsson, P. (2003). The Business Platform: Developing an Instrument to Gauge and to Assist the Development of Young Firms. Journal of Small Business Management, 4I (I), I-26.

MACKINNON, D. (1962). The nature and nurture of creative talent. American Psychologist, 17(7), 484-495.

MILLWARD, L., Freeman, H. (2002). Role Expectations as Constraints to Innovation: The Case of Female Managers. Creativity Research Journal, 14(I), 93-109.

MOORE, D. (1990). An Examination of Present Research on the Female Entrepreneur- Suggested Research Strategies for the 1990's. Journal of Business Ethics, 9(4/5), 275-28I.

MOWERY, D., Sampat, B. (2005). Universities in National Innovation Systems. In: Fagerberg, J., Mowery, D., Nelson, R. (Eds.) Oxford Handbook of innovation. Oxford University Press, Oxford.

MUZINICH, N., Pecoticha, A., Putrevu, S. (2003). A model of the antecedents and consequents of female fashion innovativeness. Journal of Retailing and Consumer Services, I0(5), 297-310.

NYBERG, A-C. (2009). Making Ideas Matter. Gender, Technology and Women's Invention. Luleå University, Luleå.

OECD (2005). Oslo manual. Guidelines for collecting and interpreting innovation data. Third Edition. OECD \& EUROSTAT, Luxemburg.

PAECHTER, C. (2003). Power/knowledge, gender and curriculum change, Journal of Educational Change, 4(2), I29148.

PIANTA, M. (2005). Innovation and Employment. In: Fagerberg, J., Mowery, D., Nelson, R. (Eds.) Oxford Handbook of innovation. Oxford University Press, Oxford.

POWELL, W., Grodal, S. (2005). Networks of Innovators. In Fagerberg, J., Mowery, D. \& Nelson, R. (Eds.) Oxford Handbook of innovation. Oxford University Press, Oxford. 
REIJ, C., Waters-Bayer, A. (200I) Farmer innovation in Africa. A source of inspiration for agricultural development

REIS, S. (2002). Toward a Theory of Creativity in Diverse Creative Women. Creativity Research Journal. 14(3/4), 305316.

SANDEMOSE, A. (1936). A Fugitive Crosses His Tracks. Alfred Knopf, New York

SHANE, S., Venkataraman, S. (200I). Entrepreneurship As a Field of Research: A Response to Zahra and Dess, Singh, and Erikson. Academy of Management Review. 26(I), I3-16.

SIEGEL, S. Castellan, N. J. (1988). Nonparametric statistics for the behavioural sciences. McGraw-Hill, New York

SINGH, R. (200I). A Comment on Developing the Field of Entrepreneurship Through the Study of Opportunity Recognition and Exploitation. Academy of Management Review. 26(I), 10-12.

STATISTICS SWEDEN, SSYK, Standard för svensk yrkesklassificering 2008, from Statistics Sweden web site http://www.ssd.scb.se/databaser/makro/Visavar.asp?yp=ddd bbf\&xu=9648700 I \&omradekod $=$ AM\&huvudtabell $=$ YREG33 \&omradetext=Arbetsmarknad\&tabelltext $=$ Anst\%E4IIda +16 \%2D64+\%E5r+i+riket+efter+yrke+\%28SSYK4\%29\%2C+ar betsst\%E4llets+sektortillh\%F6righet+och+k\%F6n\%2E+\%C5 r\&preskat=O\&prodid=AM0208\&deltabell=\&deltabellnamn $=$ Anst\%E4IIda+16\%2D64+\%E5 $r+i+r i k e t+$ efter+yrke+\%28SS YK4\%29\%2C+arbetsst\%E4llets+sektortillh\%F6righet+och+ k\%F6n\%2E+\%C5r\&innehall=Anstallda\&starttid=2005\&stop ptid=2008\&Fromwhere=M\&lang $=\mid$ \&langdb $=1$ [Accessed March 31]

SUNDIN, E. Holmquist, C. (1989) Kvinnor som företagare: osynlighet, mångfald, anpassning. Liber, Malmö

THE ECONOMIST (2010). "Wominnovation. Some innovations help women more than others". http://www.economist.com/business-finance/displaystory. cfm?story id=15656289 [Accessed April 19, 2010]
TUNZELMANN, N., Acha, V. (2005). Innovation in lowtech industries. In: Fagerberg, J., Mowery, D., Nelson, R. (Eds.) Oxford Handbook of innovation. Oxford University Press, Oxford.

URAY, N., Dedeoglu, A. (1998). Identifying Fashion Clothing Innovators by Self-Report Method. Journal of Euromarketing, 6(3), 27-46.

WARWICK, D., Reimersa, F., McGinna, N. (1992). The implementation of educational innovations: Lessons from Pakistan. International Journal of Educational Development, 12(4), 297-307.

ZAHRA, S., Dess, G. (200I). Entrepreneurship as a Field of Research: Encouraging Dialogue and Debate. Academy of Management Review, 26(I) 8-10. 